\title{
Pendidikan Kesehatan tentang Meningkatkan Kebugaran Jasmani pada Lansia Di RW III Kebraon, Karang Pilang Surabaya
}

\author{
Dwi Purwantini $^{1}$, Kresna Adji Kurniawan ${ }^{2}$ \\ 1-2 Prodi Fisioterapi STIKES Katolik St. Vincentius a Paulo \\ Email:dwiphysio@gmail.com
}

Submitted : 09/12/2021

Accepted: 08/01/2022

Published: 28/01/2022

\begin{abstract}
The covid-19 pandemic situation has occurred more than 1 year, so many people do not do much activities outdoor. This has impact on the health and physical fitness of the elderly in RW III, Kebraon, Karang Pilang Surabaya. Objective: Health education about effort to improve physical fitness in the elderly can be a solution to improve the qualityof life of the elderly during a pandemic. Methods: used in this communityservice are lectures, leaflet, and question and answers. This community service is carried out for elderly in RW III Kebraon, Karang Pilang, Surabaya. 30 elderly and elderly posyandu cadre participated in this activity. Result: the result obtained in this community service were an increase in behavioral aspects of knowledge about physical fitness increased by 100\%, types of physical activity that can improve physical fitness in increased 93\%, elderly who understood the benefit of physical activity increased $87 \%$, and $63 \%$ of the elderly would do physical activity in accordance with the appropriate dose. Based on the result ont community service, it can be concluded that helath education is very effective, thereby increasing the elderly's understanding of the benefits of exercise and physical activity, type of activity and dose of the exercise that can improve physical fitness in the elderly
\end{abstract}

Keywords: elderly, health education, physical fitness

\begin{abstract}
Abstrak
Situasi pandemic covid-19 sudah terjadi lebih dari 1 tahun membuat banyak orang tidak banyak beraktivitas di luar rumah. Hal ini berdampak pada kesehatan dan kebugaran jasmani pada lanjut usia RW III kelurahan Kebraon, Karang Pilang, Surabaya. Tujuan: Pendidikan kesehatan tentang upaya meningkatkan kebugaran jasmani pada lanjut usia dapat menjadi solusi untuk meningkatkan kualitas hidup lansia di masa pandemic. Metode: yang digunakan pada Pengabdian masyarakat ini adalah ceramah, leaflet, dan Tanya jawab. Pengabdian masyarakat in dilakukan pada Lansia di RW III kelurahan Kebraon, Karang Pilang Surabaya. 30 lansia dan kader posyandu lansia berpartisipasi pada kegiatan ini. Hasil: hasil yang didapatkan pada pengabdian masyarakat ini adanya peningkatan aspek perilaku pada pengetahuan tentang kebugaran jasmani meningkat $100 \%$, jenis aktivitas fisik yang dapat meningkatkan kebugaran jasmani meningkat 93\%, lansia yang memahami manfaat aktivitas fisik meningkat $87 \%$, dan $63 \%$ lansia akan melakukan aktivitas fisik sesuai dengan dosis yang seharusnya. Berdasarkan hasil pengabdian masyarakat dapat disimpulkan bahwa pendidikan kesehatan sangat efektif, sehingga meningkatkan pemahaman lansia akan manfaat dari olahraga dan aktivitas fisik, jenis aktivitas dan dosis latihan yang dapat meningkatkan kebugaran jasmani pada lanjut usia
\end{abstract}

Kata kunci: kebugaran jasmani, lansia, pendidikan kesehatan

\section{PENDAHULUAN}

Lanjut usia (lansia) bukan suatu penyakit, namun merupakan tahap lanjut dari suatu proses kehidupan yang ditandai dengan penurunan kemampuan tubuh untuk beradaptasi dengan stress lingkungan. Penurunan kemampuan berbagai organ, fungsi, dan stres lingkungan itu bersifat alamiah/ fisiologis. Menurut Peraturan Pemerintah Republik Indonesia Nomor 43 tahun 2014, lanjut usia adalah seseorang yang telah mencapai usia 60 (enam puluh) tahun ke atas (Kementerian Kesehatan RI, 2017). Namun awal masalah kesehatan 
pada lansia dimulai awal 50 tahun atau mungkin pada usia 40 tahun (Multani \& Verma, 2012).

Besarnya jumlah penduduk lansia di Indonesia di masa depan membawa dampak positif maupun negatif. Berdampak positif apabila penduduk lansia berada dalam keadaan sehat, aktif dan produktif. Di sisi lain, besarnya jumlah penduduk lansia menjadi beban jika lansia memiliki masalah penurunan kesehatan yang berakibat pada peningkatan disabilitas terhadap penduduk lansia (Kementerian Kesehatan RI, 2017). Berdasarkan data Riset Kesehatan Dasar (Riskesdas) tahun 2013, penyakit terbanyak diderita lansia ialah hipertensi $(57,6 \%)$, artritis $(51,9 \%)$, dan stroke $(46,1 \%)$ (Riskesdas, 2013).

Situasi pandemic covid-19 sudah terjadi lebih dari 1 tahun membuat banyak orang tidak banyak beraktivitas di luar rumah. Hal ini berdampak pada kesehatan dan kebugaran jasmani pada lanjut usia. RW III kelurahan Kebraon terdiri dari 9 RT dan setiap RT terdapat 15-20 lanjut usia. Lansia di RW III kelurahan Kebraon ratarata usia 59-72 tahun dengan jumlah lansia perempuan lebih banyak dibandingkan lansia laki-laki. Lansia di RW III ini terdiri dari pensiunan dan ibu rumah tangga, beberapa pensiunan ada yang guru, perawat, pegawai bank, pegawai kantoran dan ibu rumah tangga. Lansia di RW III Kelurahan Kebraon yang sebelumnya aktif mengadakan kegiatan menjadi berhenti oleh karena adanya pembatasan aktivitas di luar rumah. Lanjut usia di RW III sebelumnya aktif berkegiatan, seperti: senam aerobic low impac, posyandu lansia, senam pernafasan yang rutin diadakan.

Permasalahan ini disadari oleh ibu RW sebagai kader lansia yang merupakan mitra PKM bahwa dengan berhentinya aktivitas lansia ini ada memberikan dampak bagi kesehatan dan kebugaran pada lansia. Kegiatan posyandu lansia dan senam yang diadakan untuk memberikan kegiatan pada lansia supaya tetap dapat bersosialisasi, sehat dan aktif sehingga dapat meningkatkan kualitas hidupnya. Kondisi pandemi yang mulai melandai pada sekitar bulan Mei 2021, kader lansia mulai mengadakan kembali kegiatan senam yang diikuti beberapa lansia dengan menerapkan protokol kesehatan dan jumlah lansia yang terbatas.

Keinginan lansia untuk kembali beraktivitas sangat dipahami oleh kader lansia. Meskipun masih beresiko dengan melakukan aktivitas di luar rumah, lansia di RW III sebagian mengikuti kegiatan senam tersebut. Beberapa lansia menyampaikan dengan aktivitas yang sebelumnya berhenti membuat merasa tidak bugar, cepat capek dan mengantuk. Idealnya untuk lansia dibutuhkan olahraga atau aktivitas fisik dengan intensitas moderate untuk mempertahankan kebugaran jasmani (Bushman, 2017). Olahraga dan aktivitas fisik yang dilakukan sebaiknya yang dapat membantu meningkatkan kebugaran kardiorespirasi, meningkatkan kekuatan otot dan ketahanan, fleksibilitas, kelincahan, keseimbangan dan koordinasinya (Hoeger \& Hoeger, 2011). Olahraga yang disarankan senam aerobic, dan aktivitas fisik yang disarankan bagi lansia, yaitu kalistenik, jalan, jogging, bersepeda, dan aerobic di air. Lansia sebaiknya menghindari aktivitas yang bersifat isometric dan latihan dengan intensitas tinggi (Hoeger \& Hoeger, 2011).

Bagi lansia perlu menjadikan latihan fisik/ olahraga dan aktivitas fisik menjadi suatu kebiasaan yang dapat meningkatkan kesehatan, kapasitas fungsional, kualitas hidup dan kemandirian pada lansia (Mazzeo \& Tanaka, 2001), juga mengurangi permasalahan yang dapat terjad karena faktor usia

Upaya untuk meningkatkan kesehatan dilakukan melalui pendidikan kesehatan yang lebih mengutamakan upaya peningkatan pencegahan dan pemeliharaan kesehatan di samping upaya penyembuhan dan pemulihan. Upaya yang dapat 
dilakukan untuk membantu lanisa d RW III akan dilakukan pendidikan kesehatan melalui penyuluhan kesehatan Penyuluhan kesehatan sebagai penerapan promosi kesehatan merupakan bentuk upaya pelayanan kesehatan yang berorientasi pada penyampaian informasi tentang kesehatan guna penanaman pengetahuan tentang kesehatan sehingga tumbuh kesadaran untuk hidup sehat

\section{TARGET DAN LUARAN}

1. Target

Target dari pengabdian masyarakat adalah lansia baik perempuan dan laki-laki serta kader lansia di RW III Kelurahan Kebraon, Karang Pilang, Surabaya

\section{Luaran}

Setelah dilakukan pendidikan kesehatan tentang upaya meningkatkan kebugaran jasmani pada lanjut usia, diharapkan peserta dapat meningkatkan pemahaman tentang manfaat dan pentingnya aktivitas fisik dan olahraga bagi lanjut usia, jenis aktivitas fisik dan dosis latihan serta mampu memotivasi melakukan aktivitas mandiri saat pembatasan berkumpul.

\section{METODE PELAKSANAAN}

Kegiatan pengabdian pada masyarakat ini dilakukan pada bulan Juni 2021 dalam 3 tahapan. Tahap pertama dilakukan tanggal 11 Juni 2021. Pelaksanaan kegiatan pengabdian melakukan diskusi dengan ibu RW III selaku kader lansia tentang rencana kegiatan pengabdian.

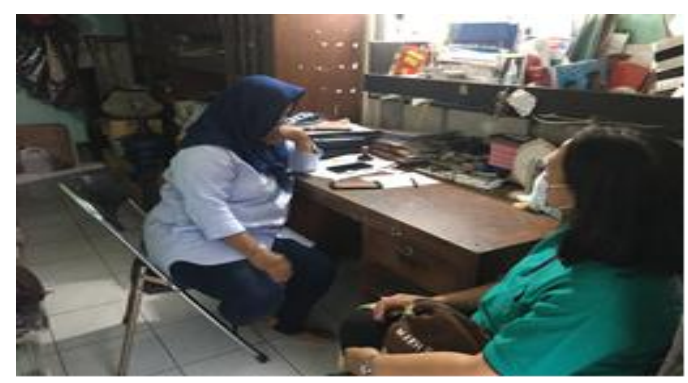

Gambar 1. Diskusi Rencana Abdimas
Tahapan yang kedua dilakukan pada tanggal 14-15 Juni 2021 yaitu menyiapkan media informasi berupa leaflet tentang meningkatkan kebugaran pada lansia. Leaflet ini berisi pengertian kebugaran jasmani, olahraga dan aktivitas apa yang dapat dilakukan untuk meningkatkan kebugaran jasmani, dosis aktivitas fisik dan latihan apa yang harus dihindari untuk lansia

Metode dan media yang digunakan dalam pemecahan masalah yang dilakukan pada kegiatan ini adalah penyuluhan dilakukan dengan metode ceramah dengan menggunakan leaflet dan Tanya jawab.

Tahap ke-3 adalah pemberian pendidikan kesehatan pada lansia tentang bagaimana meningkatkan kebugaran pada lansia pada tanggal 26 Juni 2021. Kegiatan ini diikuti oleh 30 lansia yang terdiri dari 25 lansia perempuan dan 5 lansia laki-laki, dengan rentang usia mulai 60-74 tahun. Kegiatan ini diawali dengan mengukur tensi dan nadi pada lansia dan evaluasi awal dengan mengisi kuisioner tentang aktivitas fisik dan manfaatnya. Selanjutnya adalah senam aerobic low impac. Setelah senam diberikan ceramah, dilanjutkan diskusi tentang manfaat dan pentingnya aktivitas fisik.

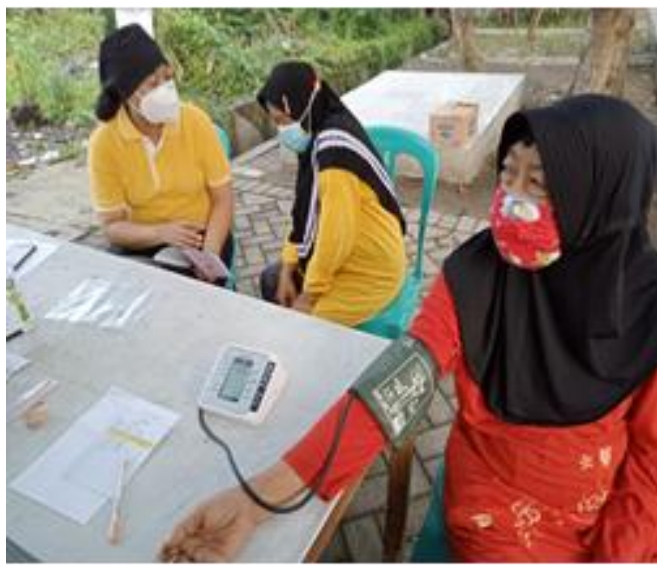

Gambar 2. Menjelaskan leaflet dan pengukuran tensi dan nadi sebelum senam 


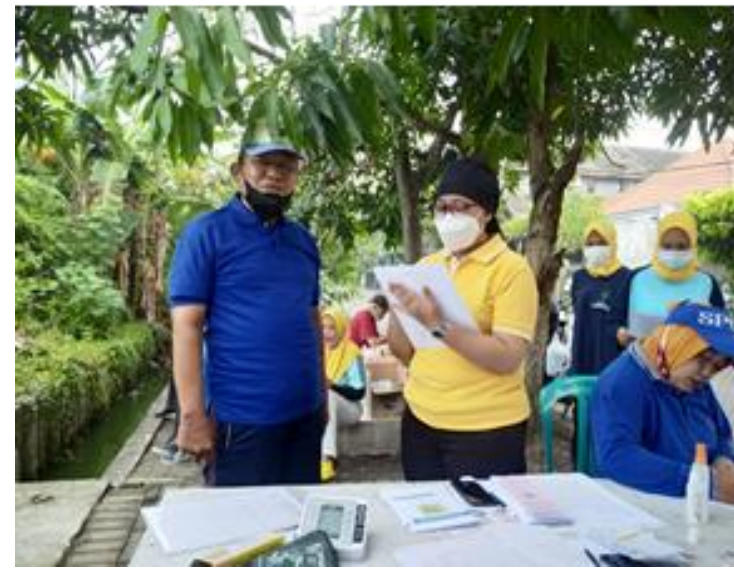

Gambar 3. Membantu mengisi kuisioner

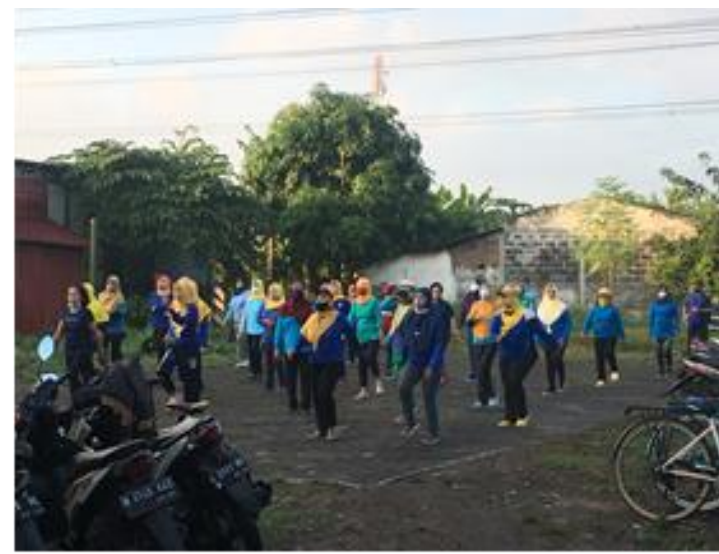

Gambar 4. Melakukan Senam Aerobik

Tahap selanjutnya adalah memberikan pendidikan kesehatan dengan ceramah dan contoh aktivitas fisik apa saja yang dapat meningkatkan kebugaran jasmani pada lansia.

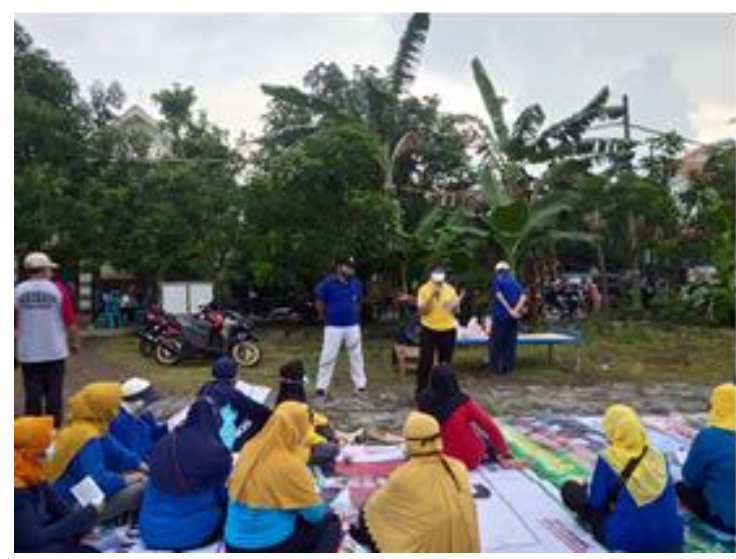

Gambar 5. Memberikan penyuluhan
Berisi waktu pelaksanaan, tahapan pelaksanaan kegiatan, teknik atau bentuk kegiatan, serta gambaran pelaksanaannya.

\section{HASIL DAN PEMBAHASAN}

Hasil evaluasi sesudah pelaksanaan dengan memberikan memberikan pertanyaan dan meminta lansia yang hadir langsung menjawabnya dan didapatkan hasil sebagai berikut

\begin{tabular}{lcc} 
Tabel 1. Hasil evaluasi & & \\
\hline \multicolumn{1}{c}{ Aspek Perilaku } & Jumlah & Prosentase \\
\hline $\begin{array}{l}\text { Pengetahuan tentang } \\
\text { Kebugaran jasmani } \\
\text { Meningkat }\end{array}$ & & \\
Tidak meningkat & 30 & $100 \%$ \\
Pengetahuan tentang jenis- & 0 & $0 \%$ \\
jenis aktivitas fisik yang & & \\
dapat meningkatkan & & \\
kebugaran jasmani & & \\
Meningkat & & \\
Tidak meningkat & 28 & $93 \%$ \\
Memahami akibat aktivitas & 2 & $0,7 \%$ \\
fisik tidak teratur pada & & \\
lansia & & \\
Ya & 27 & $87 \%$ \\
Tidak & 3 & $13 \%$ \\
Rencana melakukan & & \\
aktivitas fisik & & \\
3-5x/minggu & & \\
Ya & 19 & $63 \%$ \\
Tidak & 11 & $37 \%$ \\
\hline & & \\
& &
\end{tabular}

Dari tabel diatas didapatkan data bahwa terdapat peningkatan pengetahuan setelah diberikan pendidikan kesehatan. Mayoritas lansia (100\%) yang mengikuti kegiatan pengabdian kepada masyarakat menyampaikan mereka lebih memahami tentang kebugaran jasmani dan memahami dosis aktivitas fisik yang tepat untuk meningkatkan kebugaran. Sebagian besar lansia (93\%) mengetahui aktivitas fisik apa saja yang dapat meningkatkan kebugaran jasmani selain senam aerobic. Lebih dari $50 \%(87 \%)$ menjadi lebih memahami resiko atau akibat aktivitas fisik yang tidak teratur atau gaya hidup sedenter, tetapi hanya $37 \%$ yang mengungkapkan akan atau berencana untuk melakukan aktivitas fisik sesuai 
dengan dosis yang tepat untuk meningkatkan kebugaran jasmani pada lansia.

Hasil pengadian menunjukkan adanya peningkatan pengetahuan dan sikap dari para lansia tentang kebugaran jasmani, dosis latihan dan resiko gaya hidup yang tidak aktif. Lansia jadi lebih memahami bahwa untuk meningkatkan kebugaran jasmani tidak hanya dengan mengikuti senam aerobic, tapi dapat juga melakukan aktivitas=aktivitas lain seperti berkebun (Bushman, 2017), menari tradisional (Douka et al., 2019). Situasi pandemi membatasi lansia untuk beraktivitas di luar rumah sehingga dapat melakukan aktivitas fisik tanpa harus keluar rumah. Selain senam yang sifatnya aerobic, lansia juga dapat melakukan latihan penguatan otot dengan menggunakan barbel atau botol aqua juga latihan penguluran untuk meningkatkan kebugaran jasmani (Bushman, 2017). Latihan yang disarankan untuk lansia adalah latihan dengan intensitas moderate aktivitas aerobik 2 jam 30 menit (150 menit) per-minggu (Guccione et al., 2012). Para lansia juga lebih memahami resiko aktivitas fisik yang teratur akan mencegah resiko sakit jantung, diabetes tipe 2, beberapa jenis kanker (payudara, prostat), menurunkan kolesterol jahat (low-density lipoprotein/ LDL cholesterol) dan meningkatkan kolesterol baik (high-density lipoprotein/ HDL cholesterol) (Bushman, 2017). Semua informasi yang disampaikan termuat pada leaflet yang dibagikan dan semakin meningkatkan pengetahuan lansia.

Hasil evaluasi menunjukkan masih ada lansia yang belum dalam waktu dekat memiliki rencana untuk melakukan aktivitas sesuai dengan dosis latihan, yaitu $3-5 x$ per-minggu dengan total waktu 150 menit per minggu dengan berbagai alasan. Meskipun sudah dijelaskan dosis yang tepat untuk mendapatkan kebugaran jasmani tetapi sebagian masih merasa bahwa latihan $1-2 \mathrm{x}$ perminggu sudah cukup. Apalagi situasi pandemi membuat para lansia membatasi untuk berkegiatan di luar rumah, meskipun sudah disampaikan bahwa aktivitas fisik tetap dapat dilakukan di rumah. Dengan kondisi meminta kepada kader lansia untuk terus memotivasi lansia supaya tetap aktif melakukan aktivitas fisik sesuai dengan yang disarankan

Bagian ini menyajikan hasil pengabdian. yang meliputi luaran/fokus utama kegiatan baik langsung atau tidak langsung dengan mengaitkan sumber rujukan yang relevan Dokumentasi yang relevan dengan menyajikan foto, tabel, grafik, bagan atau gambar, keunggulan dan kelemahan luaran , tingkat kesulitan pelaksanaan kegiatan.. Pastikan tabel dengan menggunakan MsWord bukan dalam bentuk gambar. Untuk tabel dengan lebar lebih dari 1 kolom harus diletakkan di awal atau akhir halaman, sedangkan tabel dengan lebar kurang dari 1 kolom penempatannya bebas asalkan ditempatkan sesudah kalimat yang merujuknya. Setiap tabel/gambar mempunyai nomor urut

\section{KESIMPULAN DAN SARAN \\ 1. Kesimpulan}

Tingkat pengetahuan lansia di RW III

Kelurahan Kebraon, KArang Pilang Surabaya semakin meningkat setelah mendapatkan pendidikan kesehatan tentang peningkatan kebugaran jasmani pada lansia

Sebagian besar lansia mau melakukan aktivitas fisik di luar kegiatan di RW III yang dilakukan 1 minggu sekali.

$$
\text { Penyuluhan kesehatan dapat }
$$
digunakan sebagai salah satu cara meningkatkan pengetahuan masyarakat tentang masalah kesehatan

\section{Saran}

Saran bagi sudah secara rutin mengikuti senam aerobic difasilitasi oleh kader 1x dalam seminggu, menambah aktivitas fisik lain yang dapat dilakukan secara mandiri untuk memenuhi dosis latihan yang berguna untuk 
mempertahankan kesehatan dan meningkatkan kebugaran

\section{UCAPAN TERIMAKASIH}

Terimakasih kepada Lansia di RW III kelurahan Kebraon, kecamatan Karang Pilang, Surabaya dan ibu RW III selaku kader posyandu Lansia. STIKES Katolik St. Vincentius a Paulo yang sudah mendanai kegiatan pengabdian masyarakat.

\section{DAFTAR PUSTAKA}

Bushman, B. A. (2017). ACSM, Complete Guide to Fitness \& Health (Second edi). Human Kinetics.

Douka, S., Zilidou, V. I., Lilou, O., \& Manou, V. (2019). Traditional dance improves the physical fitness and wellbeing of the elderly. Frontiers in Aging Neuroscience, 11(APR), 1-9. https://doi.org/10.3389/fnagi.2019.000 75

Guccione, A., Wong, R., \& Avers, D. (2012). Geriatric Physical Therapy (Third Edit). Elsevier Mosby.

Hoeger, W. W. K., \& Hoeger, S. A. (2011). Lifetime Physical Fitness and Wellness A Personalized Program (Eleventh e). Wadworth, Cengage Learning.

Kementerian Kesehatan RI. (2017). Analisis Lansia di Indonesia (Pusat Data dan Informasi (ed.)).

Mazzeo, R. S., \& Tanaka, H. (2001). Exercise prescription for the elderly: Current recommendations. Sports Medicine, 31(11), 809-818. https://doi.org/10.2165/00007256200131110-00003

Multani, N., \& Verma, S. (2012). Principles of Geriatic Physiotherapy. Jaypee Brother Medical Publishers.

Riskesdas. (2013). Riset Kesehatan Dasar. 